\title{
Review of environmental performance of permeable pavement systems: state of the knowledge
}

\author{
Jennifer A. P. Drake, Andrea Bradford and Jiri Marsalek
}

\begin{abstract}
Permeable pavement (PP) systems provide opportunities to mitigate the impacts of urbanization on receiving water systems by providing at source treatment and management of stormwater. However, they do not receive mainstream use throughout much of Canada and the USA because of a lack of local guidance documents, demonstration projects and performance data. Studies have repeatedly shown that PPs attenuate stormwater flows by reducing volume and frequency of stormwater flows, reducing and delaying peak flow rates, and increasing flow durations. PP systems have been shown to improve stormwater quality by reducing stormwater temperature, pollutant concentrations and pollutant loadings of suspended solids, heavy metals, polyaromatic hydrocarbons, and some nutrients. This review is intended as a comprehensive summary of the current state of knowledge of the environmental performance of PP systems. Published research is synthesized to examine the hydrologic performance, impacts to water quality, longevity and functionality and maintenance needs of PP systems. Where appropriate, the limitations of current knowledge are discussed and emerging and future research needs are presented. The intent of this review is to provide stakeholders in stormwater management with the critical information that is needed to foster

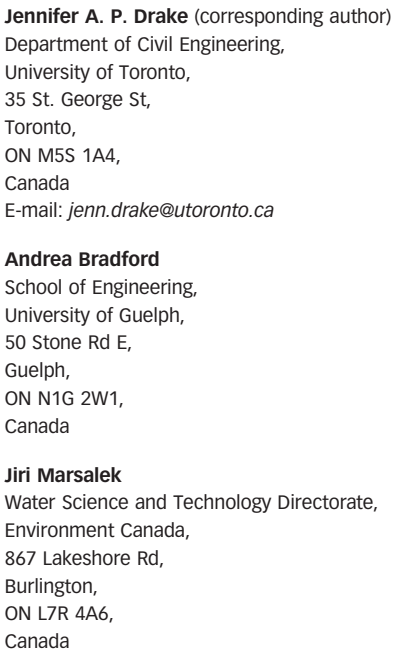
acceptance of PPs as a viable alternative to traditional systems.

Key words | hydrology, low impact development, maintenance, permeable pavements, stormwater management, water quality

\section{INTRODUCTION}

The protection of natural water balances and flow paths is a critical design objective for integrated urban stormwater management. This objective aims to mitigate or prevent disruptions to natural processes that have been shown to: contribute to unhealthy stream systems (Walsh et al. 2005); increase risks to public safety and property (Marsalek \& Chocat 2002); or degrade surface and subsurface drinking water sources (Marsalek \& Chocat 2002). The range and complexity of economic, environmental, social and cultural impacts associated with urban stormwater necessitate the use of new types of planning techniques and engineered systems. Low impact development (LID) is an increasingly accepted approach for addressing the challenges of stormwater design and management. LID is a design philosophy, encompassing planning methods doi: $10.2166 /$ wqrjc. 2013.055 and stormwater management technologies, to minimize the negative impacts most commonly associated with urban stormwater including degradation of groundwater and surface water quality, loss of recharge, erosion, flooding and loss of aquatic diversity (Coffman 2000; Dietz 2007; CVC \& TRCA 20Io). To emulate pre-development conditions, LID systems treat locally and manage, at source, as much stormwater as possible.

Permeable pavement (PP) is a key LID technology, increasing the volume of locally managed stormwater through subsurface storage and, where possible and environmentally safe, groundwater recharge. Water quality benefits of PP systems include thermal mitigation and reduced pollutant concentrations and overall loading for receiving systems. PPs have been applied in parking lots, low-density 
traffic lanes and pedestrian pathways as part of numerous experimental and demonstration programmes since the 1980s in the United States (e.g. Field et al. I982a, b), Canada (e.g. James \& Thompson 1997; James \& Verspagen 1997; Kresin et al. 1997), Europe (e.g. Pratt et al. 1989, 1995; Baladès et al. 1995; Colandini et al. 1995) and Japan (e.g. Watanabe 1995; Fujita 1997). Given the potential benefits associated with this technology, coupled with the large body of literature documenting the successful use of PP, it is perhaps surprising that PPs have not been more broadly applied across Canada and the USA. One reason for this is a limited understanding of the long-term environmental impacts of stormwater infiltration, particularly on groundwater resources and in cold climate conditions. Developers, designers, engineers, and planners are reluctant to implement technologies which are perceived to be untested with respect to longevity, sustainable performance and maintenance costs. Regionally, technical resources which provide design guidance and outline benefits and limitations of PPs are often lacking. Ongoing advances have meant that even extensive reviews such as Ferguson's (2005) book, Porous Pavement, require updating.

This review provides a synthesis of the current state of knowledge with respect to PP systems. It describes the types of PP currently available, the typical components of PP systems, and clarifies the appropriate use of PP as an LID technology. Approaches to studying and evaluating PPs are highly variable and this review aims to provide critical interpretations of existing studies to advance the current understanding of hydrologic performance, impacts to water quality, longevity and functionality and maintenance needs. Finally, the paper identifies emerging research and needs.

\section{BACKGROUND}

A permeable (also called porous or pervious) pavement is a paving material which allows water to infiltrate and be conveyed through its material matrix, open joints or voids. While some researchers (Beecham \& Myers 2007) have drawn a distinction, the terms permeable, porous and pervious are frequently used interchangeably. PP systems are composed of a permeable paving surface as well as layers of coarse aggregate materials that function as an aggregate reservoir, providing storage capacity during precipitation events (Figure 1). Depending on site conditions, pavements can be designed with different boundary components for full, partial or no exfiltration (i.e. infiltration to native soils). When exfiltration is not desired, underdrains composed of perforated pipes are positioned at or near the base of the aggregate reservoir to collect and convey infiltrating water to a storm sewer system, with or without further treatment. Some PP parking lots have been designed with vault storage, allowing further control of outflow and interception of spills. Stormwater which has infiltrated through a PP system and been collected in an underdrain is referred to as exfiltrate (Sansalone \& Teng 2004; Bean et al. 2007a) or outflow. Elevating underdrains so that they are located above the base of the aggregate reservoir increases the degree of partial exfiltration as water levels must rise to the elevation of the underdrain invert before stormwater can drain through these pipes. Other components commonly included in the design of PP systems are geotextiles, and small aggregate filter or choker courses. PPs have also been applied as overlays (referred to as a permeable friction course or an open-graded friction course) on highways. In this application infiltration to native soils is not a design objective but rather the porous properties of the PP are used to reduce spray and traffic noise (Barrett et al. 2006; Schaefer et al. 20I0).

Ferguson (2005) identified nine types of PP based on surface paving material: porous aggregate, porous turf, plastic geocells, open-jointed paving blocks or permeable

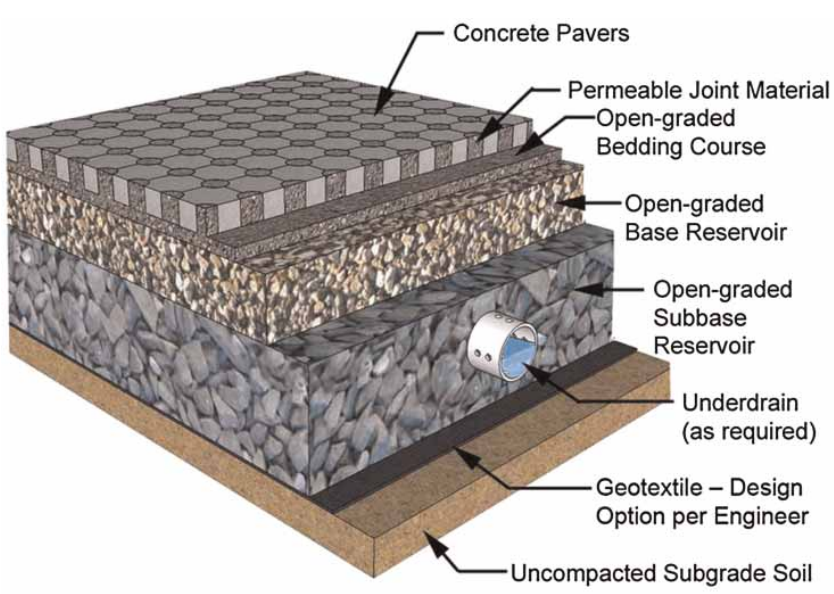

Figure 1 | Example of a typical PP cross-section (image used with permission of the Interlocking Concrete Pavement Institute). 
interlocking concrete pavers, open-celled paving grids, porous concrete (or pervious concrete), porous asphalt, soft paving materials and decks. In addition to these categories a tenth type, epoxy-bonded porous materials, has been developed (e.g. Flexi ${ }^{\circledR}$-Pave and FilterPave ${ }^{\circledR}$ ).

Each type of PP has different functional, environmental, aesthetic and cost requirements. Most research has focussed on the more commercially applied materials: permeable interlocking concrete pavers, pervious concrete, and porous asphalt, and these types are the focus of this review. Permeable interlocking concrete pavers (PICPs) consist of modular units separated by joints filled with open-graded aggregate. Pervious concrete $(\mathrm{PC})$ and porous asphalt (PA) are permeable variations of concrete or asphalt where the binding agent coats the aggregate particles without filling the voids between the particles (Kevern et al. 20Io). These pavement types are capable of supporting vehicular traffic, require limited maintenance, and are aesthetically pleasing and affordable, making them suitable alternatives for parking lot, pedestrian and low-density traffic roadways. Designed correctly, PPs can be successfully applied for a broad range of traffic loadings; for example PICPs were used in airport fire training grounds in the UK (Knapton \& Cook 2003) and in container handling areas in Brazil (Knapton \& Cook 200o).

In addition to traffic loads, the design of a PP system depends on the climate, native soils, hydrology and land use of the site and adjacent lands. Infiltration to native soils may not be possible or suitable at all sites such as those with low permeability native soils, soil contamination, or existing or future land uses that may lead to poor stormwater quality (i.e. hot-spots) and risks to groundwater quality (CVC \& TRCA 20Io). In northern climates deicing salts applied during the winter may present environmental concerns for down-gradient systems; chloride in particular is expected to pass through the pavement structure largely unattenuated (CVC \& TRCA 20IO). Sand and gravel used for winter road maintenance can cause clogging of PP systems and its use is not recommended (CVC \& TRCA 20IO). PPs are also not feasible in areas where clogging material is likely to be directed onto the pavement, for example sites adjacent to beaches (Ferguson 2005).

\section{HYDROLOGIC PERFORMANCE}

The potential hydrological benefits of PP systems were initially reported by Thelen et al. (I972) to the US Environmental Protection Agency and since that time, hydrological performance has been a prominent theme in much of the literature. This review focusses on the results from monitoring and testing of full-scale parking lots, designed to accommodate monitoring equipment and subjected to traffic and natural precipitation.

Research objectives typically focus on quantifying the water balance and measuring the timing and rate of flows. Hydrologic results are dependent on local climatic and geological conditions, confounding efforts to compare performance between studies. Differences in system design, particularly boundary components (i.e. type of underdrainage), as well as the condition and age of a pavement, are also critical to performance comparisons. To fully characterize the hydrologic behaviour, a PP system must be monitored under a range of conditions (e.g. storm events of varying magnitude, intensity and duration, and different antecedent and seasonally variable conditions). Within an installation, spatial heterogeneity is a common phenomenon due to differential inputs, traffic loadings, drainage patterns and installation and maintenance conditions across the pavement surface. Hydrologic performance of a PP system, with respect to outflow volume, rate, timing and frequency, is typically measured and reported relative to an impervious pavement 'control'.

Many of the early monitoring studies (1980-2000) from the USA, UK, and Canada were for PICP installations that used aggregate and block designs which are no longer commercially available. Field et al. (I982a, b), Pratt et al. (1989), and James \& Thompson (1997) found that even these early designs yielded promising runoff volume reductions. Some early designs were constructed with impermeable membranes which prevented exfiltration to native soils (Pratt et al. 1989; James \& Thompson 1997). Total volume reductions from systems designed for no exfiltration are notably lower than those from systems designed for exfiltration; however, Pratt et al. (1989) found that even lined systems produced no discharge for small rainfall events $(<5 \mathrm{~mm})$. More recent studies have also found that PP 
systems do not produce outflow for small events, preceded by dry antecedent conditions (Bean et al. 2007a; Drake et al. 2012).

Monitoring studies have progressively become more sophisticated, expanding the hydraulic parameters monitored beyond volume and peak flow reductions to include analysis of flow timing and duration (e.g. Roseen et al. 2009; Fassman \& Blackbourn 2010a). Statistical analyses have become tools for performance evaluations of PP systems and researchers now regularly report results in terms of statistically significant differences relative to 'control' plots (Roseen et al. 2009; Collins et al. 20IO; Fassman \& Blackbourn 2010a). Booth \& Leavitt (I999) were among the first to initiate side-by-side testing of different types of PP, and Brattebo \& Booth (2003) provided an analysis of long-term performance, marking a departure from earlier studies which had limited results from a small number of isolated rainfall events. Collins et al. (2008) provide more sideby-side testing and were the first to evaluate performance differences between poured and modular PP systems.

Table 1 summarizes the hydrologic performance for a range of PP systems. The description of the systems provided in the cited studies allowed the results to be placed in context (e.g. with respect to the system design, events monitored, etc.). Poured and modular PP are expected to have similar hydrologic behaviour since outflow is ultimately governed by boundary conditions and precipitation inputs. Hydrologic performance evaluations have been almost exclusively limited to newly-constructed PP installations and studies longer than 2.5 years are rare. Differences in hydraulic behaviour between types of PP are likely to become more apparent as the pavement ages and experiences surface permeability losses.

Reported volume and peak flow reductions are variable. Surface runoff and exfiltrate volumes from PPs are generally smaller than those from asphalt pavements, but negative volume reductions (i.e. increases in outflow) are possible when stormwater previously stored within the PP system is released during an event (Abbott \& CominoMateos 2003; Drake et al. 20I2). Many studies (Kwiatkowski et al. 2007; Collins et al. 2008; TRCA 2008) have reported no direct runoff from PP during the entire monitoring period. It is difficult to document performance for larger, infrequent events unless they happen to occur during a

Table 1 | Effects of permeable pavement on runoff or exfiltration hydrograph characteristics

\begin{tabular}{|c|c|c|c|c|c|c|c|}
\hline Paper & Type & Boundary condition & $\begin{array}{l}\text { Study } \\
\text { duration }\end{array}$ & $\begin{array}{l}\text { Max } \\
\text { rainfall }\end{array}$ & Volume & Flows & Timing \\
\hline $\begin{array}{l}\text { Abbott \& } \\
\text { Comino- } \\
\text { Mateos (2003) }\end{array}$ & PICP & $\begin{array}{l}\text { Impermeable } \\
\text { liner with } \\
\text { underdrains }\end{array}$ & 14 months & $20.6 \mathrm{~mm}$ & \multirow{2}{*}{\multicolumn{2}{|c|}{$\begin{array}{l}\text { UEV averaged } \\
67 \% \text { of SRV, } \\
\text { ranged between } \\
30 \text { and } 120 \%\end{array}$}} & $\begin{array}{l}\text { PF lag averaged } \\
2 \mathrm{~h} \text {, ranged } \\
\text { between } \\
5 \text { min and } 9 \mathrm{~h}\end{array}$ \\
\hline Barrett (2008) & PA (overlay) & $\begin{array}{l}\text { Conventional } \\
\text { asphalt }\end{array}$ & 2.5 years & $117 \mathrm{~mm}$ & & & $\begin{array}{l}\text { Minimal lag } \\
\text { between peak } \\
\text { rainfall and } \\
\text { runoff }\end{array}$ \\
\hline \multirow[t]{3}{*}{$\begin{array}{l}\text { Bean et al. } \\
\quad(2007 \mathrm{a})\end{array}$} & CGP & Sandy soil & 26 months & $369 \mathrm{~mm}$ & $\begin{array}{l}\text { SRV was } 44 \% \text { of } \\
\text { RV on average }\end{array}$ & & $\begin{array}{l}22 \% \text { of all } \\
\text { events } \\
\text { produced } \\
\text { runoff }\end{array}$ \\
\hline & PC & Sandy soil & 17 months & $97 \mathrm{~mm}$ & \multirow[t]{2}{*}{$\begin{array}{l}\text { SRV was } 31 \% \text { of } \\
\text { RV on average }\end{array}$} & & $\begin{array}{l}37 \% \text { of all } \\
\text { events } \\
\text { produced } \\
\text { runoff }>1 \mathrm{~mm}\end{array}$ \\
\hline & CGP & $\begin{array}{l}\text { Sandy soils and } \\
\text { loam sand soil } \\
\text { with } \\
\text { underdrains }\end{array}$ & 10 months & $88 \mathrm{~mm}$ & & & $\begin{array}{l}\text { No runoff } \\
\text { observed }\end{array}$ \\
\hline
\end{tabular}




\begin{tabular}{|c|c|c|c|c|c|c|c|}
\hline Paper & Type & Boundary condition & $\begin{array}{l}\text { Study } \\
\text { duration }\end{array}$ & $\begin{array}{l}\text { Max } \\
\text { rainfall }\end{array}$ & Volume & Flows & Timing \\
\hline $\begin{array}{l}\text { Collins et al. } \\
\text { (2008) }\end{array}$ & $\begin{array}{l}\text { PICP } \\
\text { PC } \\
\text { CGP }\end{array}$ & $\begin{array}{l}\text { Sandy loam to } \\
\text { sandy clay loam } \\
\text { with } \\
\text { underdrains }\end{array}$ & 12 months & $183 \mathrm{~mm}$ & $\begin{array}{l}\text { SRV was }<1 \% \text { of } \\
\text { RV, EV } \\
\text { reductions } \\
\text { averaged } 37- \\
66 \% \text {, no } \\
\text { exfiltration was } \\
\text { observed for } \\
\text { rainfall events } \\
<6 \mathrm{~mm}\end{array}$ & $\begin{array}{l}\text { PF reductions } \\
\text { averaged 67\% } \\
\text { (PC), 60-74\% } \\
\text { (PICP), 77\% } \\
\text { (CGP) }\end{array}$ & $\begin{array}{l}\text { PF lag averaged } \\
28-50 \mathrm{~min}, \\
\text { ranged } \\
\text { between } 0 \\
\text { and } 312 \mathrm{~min}\end{array}$ \\
\hline $\begin{array}{l}\text { Drake et al. } \\
\quad(2 \mathrm{II} 2)\end{array}$ & $\begin{array}{l}\text { PICP } \\
\text { PC }\end{array}$ & $\begin{array}{r}\text { Silty clay with } \\
\text { underdrains }\end{array}$ & 22 months & $51.6 \mathrm{~mm}$ & $\begin{array}{l}\text { No direct runoff } \\
\text { observed, UEV } \\
\text { was } 57 \% \text { of } \\
\text { SRV }\end{array}$ & $\begin{array}{l}\text { PF reductions } \\
\quad \text { averaged } 92 \%\end{array}$ & $\begin{array}{l}\text { hydrograph lag } \\
\text { ranged } \\
\text { between } \\
45 \mathrm{~min} \text { and } \\
57.5 \mathrm{~h}\end{array}$ \\
\hline $\begin{array}{l}\text { Dreelin et al. } \\
\quad(2006)\end{array}$ & PGC & $\begin{array}{l}\text { Well-drained } \\
\text { clayey soils } \\
\text { with } \\
\text { underdrain }\end{array}$ & 4 months & 18.5 & $\begin{array}{l}\text { Direct runoff } \\
\text { reduced by } 93 \%\end{array}$ & & \\
\hline $\begin{array}{l}\text { Fassman \& } \\
\text { Blackbourn } \\
\text { (2OIOa) }\end{array}$ & PICP & $\begin{array}{l}\text { Silty clay/clayey } \\
\text { silt with } \\
\text { underdrains }\end{array}$ & 11 months & $152 \mathrm{~mm}$ & $\begin{array}{l}\text { UEV averaged } \\
72 \% \text { of SRV }\end{array}$ & $\begin{array}{l}\text { PF reduction } \\
\text { averaged } 89 \%\end{array}$ & $\begin{array}{l}\text { median PF lag } \\
\text { was } 1 \mathrm{~h}\end{array}$ \\
\hline $\begin{array}{l}\text { Kwiatkowski } \\
\text { et al. (2007) }\end{array}$ & PC & Silty sand & $\sim 2.5$ years & - & $\begin{array}{l}\text { 100\% infiltration } \\
\text { achieved for } \\
\text { rain events }<50 \\
\text { mm }\end{array}$ & & \\
\hline $\begin{array}{l}\text { Pratt et al. } \\
\text { (Ig89) }\end{array}$ & PICP & $\begin{array}{l}\text { Impermeable } \\
\text { liner with } \\
\text { underdrain }\end{array}$ & 1 month & - & $\begin{array}{l}\text { UEV was } 61-75 \% \\
\text { of RV }\end{array}$ & $\begin{array}{l}\text { PF was 30\% of } \\
\quad \text { rainfall } \\
\text { intensity }\end{array}$ & $\begin{array}{l}\text { PF lag was 5- } \\
10 \text { min }\end{array}$ \\
\hline Pratt et al. (1995) & PICP & $\begin{array}{l}\text { Impermeable } \\
\text { liner with } \\
\text { underdrains }\end{array}$ & $\sim 2$ years & $22.6 \mathrm{~mm}$ & $\begin{array}{l}\text { UEV averaged } 24- \\
47 \% \text { of } \mathrm{RV}\end{array}$ & & \\
\hline $\begin{array}{l}\text { Roseen et al. } \\
\text { (20I2) }\end{array}$ & PA & $\begin{array}{r}\text { Type 'C' soils } \\
\text { with raised } \\
\text { underdrain }\end{array}$ & 18 months & $12.7 \mathrm{~mm}$ & $\begin{array}{l}\text { No direct runoff } \\
\text { observed PP } \\
\text { infiltrated } 25 \% \\
\text { of RV }\end{array}$ & $\begin{array}{l}\text { PF reduction } \\
\quad \text { averaged } 80 \%\end{array}$ & $\begin{array}{r}\text { Hydrograph lag } \\
\text { averaged } 21 \mathrm{~h}\end{array}$ \\
\hline Rushton (200I) & $\mathrm{PP}$ & Sandy soil & $\sim 2$ years & - & $\begin{array}{l}\text { UEV was } 35 \% \text { of } \\
\text { SRV }\end{array}$ & $\begin{array}{l}\text { Reduction was } \\
\text { more } \\
\text { pronounced } \\
\text { for small rain } \\
\text { events }\end{array}$ & \\
\hline TRCA (2008) & PICP & $\begin{array}{l}\text { Impermeable } \\
\text { liner with } \\
\text { underdrains }\end{array}$ & 2.5 years & $72 \mathrm{~mm}$ & $\begin{array}{l}\text { No runoff } \\
\text { observed during } \\
\text { the summer } \\
\text { except for one } \\
\text { large rain event } \\
\text { (72 mm) }\end{array}$ & $\begin{array}{l}\text { SIR of mature } \\
\text { pavements (3- } \\
17 \text { years) } \\
\text { ranged } \\
\text { between } 3 \\
\text { and } 122 \mathrm{~cm} / \mathrm{h}\end{array}$ & \\
\hline
\end{tabular}

CGP, concrete grid pavers; PA, porous asphalt; PC, pervious concrete; PGC, Plastic GeoCells; PEF, peak exfiltrate flow; PF, peak flow; PP, permeable pavement; RV, rainfall volume; SIR, surface infiltration rate; SRV, surface runoff volume; UEV, underdrain exfiltrate volume. 
study. In the majority of studies, the volume of exfiltrated stormwater is at least $30 \%$ smaller than precipitation inputs or runoff from impermeable control pavements. As the number of hydrologic studies increases, evidence is emerging that, for small-to-moderately sized rainfall events, underdrained PPs provide a minimum degree of volume reduction regardless of location or drainage design. High volume reductions, above $30 \%$, are frequently reported for PPs draining to sandy soils (Pratt et al. I995; Rushton 200I; Abbott \& Comino-Mateos 2003; Bean et al. 2007a; Collins et al. 2008). Peak flow reductions, of $70 \%$ or more relative to an impermeable control, are commonly reported but delays in timing of peak flows are less consistent between studies and highly variable within individual studies.

Few studies have investigated the hydrologic performance of PP systems allowing exfiltration in locations with low permeability soils. Dreelin et al. (2006) discussed the hydrologic performance of an installation of porous turf over soils with high clay content. However, the reported percolation rates of the soils $(4.8-16.7 \mathrm{~cm} / \mathrm{h})$ indicate that these soils actually had high permeability. Another study of PICPs on low permeability soils by Fassman \& Blackbourn (20I0a) in New Zealand observed greater than expected volume reductions. The authors proposed that evaporation and heterogeneous features within the native soils (i.e. fractures) were the most likely explanations for the observed hydrologic losses. This highlights the issue that standard methods of estimating soil properties which rely on small soil samples can significantly underestimate the bulk hydraulic conductivity.

A number of other relevant findings emerged from the cited studies. Brattebo \& Booth (2003) found that during precipitation events, parked vehicles can create saturated conditions resulting in overland flows, by concentrating rainfall onto small sections of pavement. Tyner et al. (2009) found that constructing additional features such as infiltration trenches or boreholes, or ripping the surface at the soil layer, can increase the capacity to infiltrate water to low permeability soils. Starke et al. (20IO, 20II) showed a $16 \%$ increase in evaporation rates from PPs relative to impermeable pavements and evaporation rates were found to be dependent on sub-base materials, vegetation and stone colouring.
Laboratory-scale research can complement field studies by allowing for the hydraulic properties of PP to be evaluated under controlled conditions. It is important to use appropriate boundary conditions in laboratory-scale studies; draining pavement specimens to open-air collection systems is not realistic and may not accurately simulate performance of PP systems. Hou et al. (2010) is one study which included a low hydraulic conductivity native soil layer as a boundary condition for PP specimens. The Beijing-based researchers observed that exfiltrate water continued to flow out of the soil layer for up to 10 days after a simulated rain event.

Both laboratory and field testing are important for poured products where mix design and placement have a strong influence on hydraulic performance. Sansalone et al. (2008) developed methods to assess pore characteristics including pore size, total and effective porosity, and tortuosity for PC. Outdoor laboratory-scale studies are also useful for investigating processes such as evapotranspiration, where exposure to natural environmental conditions may be important, but measurement equipment, such as lysimeters, cannot be easily integrated into full-scale PP installations (Starke et al. 20Io).

A key limitation of the existing research is that the most extensive monitoring studies (Table 1) have only looked at performance over 2.5 years which is a fraction of a pavement system's effective life; long-term (i.e. life-cycle) performance remains largely untested. There has been limited use of poured permeable products such as PC, PA and epoxybased materials in many cold-climate regions and further demonstration and testing of these systems is merited.

\section{IMPACTS ON WATER QUALITY}

PP systems reduce the total pollutant mass delivered to receiving systems by reducing runoff and outflow volumes and removing pollutants from stormwater (Bean et al. 2007a). Pollutants are introduced into stormwater through a range of anthropogenic activities and environmental processes. During periods of dry weather suspended materials are deposited on pavements by vehicular traffic as well as by atmospheric deposition. Vehicle wear leaves behind traces of heavy metals. Hydrocarbons and polycyclic aromatic hydrocarbons (PAHs) are also deposited by wearing tyres 
and oil and gas leaks. Nutrients and bacteria may be introduced by leaf litter, animal waste or tracked in from nearby areas. And lastly, winter road salting introduces chloride and other dissolved pollutants. Suspended materials within stormwater are captured by mechanical filtration through the PP surface and base layers. As water migrates through the porous media, additional treatment is possible through sorption and biologically mediated processes (Mothersill et al. 2000), including nutrient transformations and degradation of organic compounds. Pollutants which are captured by the PP accumulate overtime within the pavement and base layers and eventually require removal. Among the pollutants of interest are suspended solids, chloride, metals, nutrients, hydrocarbons, and bacteria. Temperature and $\mathrm{pH}$ are also frequently measured because they affect the solubility and toxicity of other parameters such as heavy metals. The majority of published research focusses on impacts to surface water quality; however, since many PP systems include partial or full exfiltration, PP treated stormwater can potentially impact groundwater quality (Pitt et al. 1996).

Investigative work focussed on water quality often aims to quantify the event mean concentration (EMC) for specific pollutants (e.g. total suspended solids (TSS), total nitrogen (TN), total phosphorus (TP), $\mathrm{Cu}, \mathrm{Zn}$, etc.) and to quantify reductions in terms of pollutant concentration and mass (or load) relative to impervious pavements (Legret et al. 1996; Rushton 200I). Equally as significant as event-based concentrations are the total pollutant load of contaminants produced from a pavement. Even if concentrations are not reduced by infiltration through PP (e.g. chloride is not retained within PP systems) the reduction in total volume of stormwater travelling to downstream surface water leads to a net reduction of total pollutant loads. While some research reports pollutant loads (Pagotto et al. 2000; Rushton 200I; Sansalone \& Teng 2004; Collins et al. 2010) the majority of published work does not include this information. Removal mechanisms are different for dissolved and particulate forms of pollutants, so it is important to characterize the proportions of pollutants in each of these forms within influent and effluent samples.

Starting in the 1980s, the potential benefits of PPs on stormwater quality were identified and measured by researchers. Pratt et al. (I989) reported that exfiltrated stormwater from PICPs had lower concentrations of suspended solids and total $\mathrm{Pb}$ compared to stormwater discharging from traditional highway drainage catch basins. Based on observations, Baladès et al. (1995) conservatively proposed that PPs may be capable of capturing $50-60 \%$ of certain pollutants, specifically suspended solids, $\mathrm{Pb}, \mathrm{Zn}$ and $\mathrm{Cd}$. Legret et al. (1996) also reported concentration reductions of a similar magnitude for suspended solids and metals from stormwater filtered through a PA roadway. More recent studies (Rushton 200I; Brattebo \& Booth 2003; Bean et al. 2007a; TRCA 2008; Roseen et al. 2009; Fassman \& Blackbourn 20Iob) have repeatedly found that the concentration of suspended solids and heavy metals (e.g. $\mathrm{Pb}, \mathrm{Zn}, \mathrm{Cu}, \mathrm{Cd}$ and $\mathrm{Fe}$ ) are reduced by at least $50 \%$ when stormwater filters through PP (Table 2). In many of these studies, stormwater was sampled for a small number of precipitation events (i.e. less than five events) and as independent stand-alone studies, they suffer from limited confidence in the reported results. As a collective body of evidence it is clear that the most commonly used pavements, PA, PICP and PC, remove suspended solids and studied heavy metals.

Exfiltrate from PP systems has been consistently documented to have a $\mathrm{pH}$ ranging between 8 and 9.5 (Pratt et al. 1995; Sansalone \& Teng 2004; Kwiatkowski et al. 2007; TRCA 2008), whereas rainfall and asphalt runoff tend to be acidic. For the protection of aquatic life, common water quality guidelines recommend that $\mathrm{pH}$ should be maintained between 6.5 and 8.5 (MOE 1994) and less than 9 for extreme conditions (US EPA 1986), because PP exfiltrate sometimes fails to meet these guidelines there may be impacts on aquatic life. As many metals are less soluble at elevated $\mathrm{pH}$ levels, PP systems may enhance precipitation and filtration of heavy metals, or their transformation into less bioavailable species.

When stormwater is allowed to infiltrate, hydrocarbons are retained at the pavement surface or within the permeable media where they can volatize or degrade (Pitt et al. 1996). Research has indicated that PPs provide suitable conditions for bio-degradation of hydrocarbons and the addition of microbial mixtures does not necessarily improve removal rates (Pratt et al. 1999; Newman et al. 2002). Researchers have not explicitly studied microbial populations or biofilms within PP systems in terms of growth rates, survival or diversity. Studies have reported removal rates for extractable solvents (oil and grease), 
Table 2 | Removal efficiency of common metals and suspended solids

\begin{tabular}{|c|c|c|c|c|c|c|c|c|c|c|c|c|c|}
\hline \multirow[b]{2}{*}{ Paper } & \multirow[b]{2}{*}{ Pavement } & \multirow[b]{2}{*}{$\begin{array}{l}\text { Sampled } \\
\text { events }\end{array}$} & \multicolumn{6}{|c|}{ Average removal (\%) } & \multicolumn{5}{|c|}{ Average residual concentration } \\
\hline & & & $\begin{array}{l}\text { By concentration } \\
\text { or mass }\end{array}$ & TSS & $\mathbf{z n}$ & Cu & $\mathbf{P b}$ & cd & $\begin{array}{l}\text { TSS } \\
\text { (mg/L) }\end{array}$ & $\begin{array}{l}\mathrm{Zn} \\
(\mu \mathrm{g} / \mathrm{L})\end{array}$ & $\begin{array}{l}\mathrm{Cu} \\
(\mu \mathrm{g} / \mathrm{L})\end{array}$ & $\begin{array}{l}\mathrm{Pb} \\
(\mu \mathrm{g} / \mathrm{L})\end{array}$ & $\begin{array}{l}\text { Cd } \\
(\mu \mathrm{g} / \mathrm{L})\end{array}$ \\
\hline $\begin{array}{l}\text { Barrett et al. } \\
\quad(2006)\end{array}$ & PA (overlay) & 5 & Concentration & 94 & 76 & 75 & 93 & & 7.6 & $40.4^{\mathrm{a}}, 30.9^{\mathrm{b}}$ & 6.8 & 0.9 & \\
\hline \multirow[t]{2}{*}{ Barrett (2008) } & PA (overlay) & $\begin{array}{c}5 \text { asphalt, } 25 \\
\text { exfiltrate }\end{array}$ & Concentration & 93 & 79 & 52 & 88 & & 8.80 & $34.7^{\mathrm{a}}, 27.4^{\mathrm{b}}$ & $12.9^{\mathrm{a}}, 9.8^{\mathrm{b}}$ & $1.5^{\mathrm{a}},<1.0^{\mathrm{b}}$ & \\
\hline & PA (overlay) & 6 & Concentration & 87 & 83 & 61 & 87 & & 23.17 & $23.3^{\mathrm{a}}, 13.0^{\mathrm{b}}$ & $12.4^{\mathrm{a}}, 8.4^{\mathrm{b}}$ & $1.4^{\mathrm{a}},<1.0^{\mathrm{b}}$ & \\
\hline $\begin{array}{l}\text { Fassman \& } \\
\text { Blackbourn } \\
(\text { (2OIob) }\end{array}$ & PICP & $8-17$ & $\begin{array}{l}\text { Concentration } \\
\text { Concentration }^{\mathrm{a}} \\
\text { Mass }^{\mathrm{a}} \\
\text { Mass }^{\mathrm{b}}\end{array}$ & $\begin{array}{l}56 \\
70\end{array}$ & $\begin{array}{l}93 \\
93 \\
96 \\
95\end{array}$ & $\begin{array}{l}57 \\
52 \\
70 \\
69\end{array}$ & & & $10-80$ & $8-60^{\mathrm{a}}, 0-20^{\mathrm{b}}$ & $3-8^{\mathrm{a}}, 1-3^{\mathrm{b}}$ & & \\
\hline $\begin{array}{l}\text { Legret \& } \\
\text { Colandini } \\
\text { (I999) }\end{array}$ & $\mathrm{PA}$ & 11 & Mass & 59 & 73 & & 84 & 77 & 8.3 & 45.6 & 8.3 & 0.25 & \\
\hline $\begin{array}{l}\text { Legret et al. } \\
\quad \text { (I996) }\end{array}$ & $\mathrm{PA}$ & $22-38$ & Concentration & 64 & 72 & & 79 & 67 & 12 & 46 & 15 & 5.4 & 0.49 \\
\hline $\begin{array}{l}\text { Pagotto et al. } \\
\quad(2000)\end{array}$ & $\mathrm{PA}$ & 25 & $\begin{array}{l}\text { Concentration }^{\mathrm{b}} \\
\text { Concentration }^{\mathrm{c}} \\
\text { Concentration }^{\mathrm{a}} \\
\text { Mass }^{\mathrm{a}}\end{array}$ & $\begin{array}{l}81 \\
77\end{array}$ & $\begin{array}{l}61 \\
74 \\
66 \\
59\end{array}$ & $\begin{array}{l}15 \\
70 \\
35 \\
21\end{array}$ & $\begin{array}{l}32 \\
83 \\
78 \\
74\end{array}$ & $\begin{array}{l}60 \\
73 \\
69 \\
62\end{array}$ & 13 & 180 & 24 & 13 & 0.5 \\
\hline $\begin{array}{l}\text { Roseen et al. } \\
\quad(2009)\end{array}$ & $\mathrm{PA}$ & $\begin{array}{l}\text { Unspecified, } \\
24 \\
\text { months }\end{array}$ & Concentration & 96 & 79 & & & & 2.22 & 100 & & & \\
\hline $\begin{array}{c}\text { Rushton } \\
\text { (200I) }\end{array}$ & $\begin{array}{l}\text { Porous } \\
\quad \text { paving }+ \\
\text { swale }\end{array}$ & $12-30$ & Mass & 91 & 75 & 81 & 85 & & 3.76 & 18.6 & 3.35 & 1.25 & \\
\hline $\begin{array}{l}\text { Sansalone \& } \\
\text { Teng (2004) }\end{array}$ & $\mathrm{PC}$ & 3 & $\begin{array}{l}\text { Mass }^{\mathrm{c}} \\
\text { Mass }^{\mathrm{b}} \\
\text { Concentration }^{\mathrm{c}} \\
\text { Concentration }^{\mathrm{b}}\end{array}$ & $\begin{array}{l}91 \\
72\end{array}$ & $\begin{array}{l}85 \\
91 \\
55 \\
92\end{array}$ & $\begin{array}{l}86 \\
88 \\
54 \\
62\end{array}$ & $\begin{array}{l}89 \\
76 \\
63 \\
25\end{array}$ & $\begin{array}{l}86 \\
86 \\
55 \\
54\end{array}$ & & $71.2^{\mathrm{a}}, 29.2^{\mathrm{b}}$ & $16.8^{\mathrm{a}}, 12.3^{\mathrm{b}}$ & $20.3^{\mathrm{a}}, 17.6^{\mathrm{b}}$ & $0.8^{\mathrm{a}}, 0.7^{\mathrm{b}}$ \\
\hline
\end{tabular}

aTotal.

${ }^{\mathrm{b}}$ Dissolved.

'Particulate.

PAHs, or petroleum hydrocarbons and have consistently found that levels are below detection limits (James \& Shahin 1998; Pratt et al. I999; Rushton 200I; Boving et al. 2008; TRCA 2008; Tota-Maharaj \& Scholz 20I0) indicating that hydrocarbons are not a significant pollutant in PP effluent.

High nutrient levels in stormwater contribute to excessive eutrophication which has a negative effect on surface water systems. In recent years there has been increased focus on nutrients within the published literature (Pagotto et al. 2000; Bean et al. 2007a; Roseen et al. 2009; Collins et al. 20Io; Tota-Maharaj \& Scholz 20Io). To date, Collins et al. (20I0) is the only study which intensively evaluates the transformation and fate of $\mathrm{N}$ through PP. This study concluded that PP systems provide suitable conditions for nitrification $\mathrm{NH}_{4}^{+} \rightarrow \mathrm{NO}_{3}^{-}$based on the observation that PP exfiltrate had consistently lower TKN and $\mathrm{NH}_{4}^{+}$concentrations and consistently higher $\mathrm{NO}_{3}^{-}$concentrations than asphalt runoff. Collins et al. (20IO) also observed that TN concentrations can occasionally be higher in PP effluent than in asphalt runoff and atmospheric deposition. Further work to confirm this finding and determine the source of excess nitrogen (materials used in the PP system, organic debris delivered at the surface) is needed. Several studies 
have noted reductions in TP concentrations (Bean et al. 2007a; TRCA 2008; Roseen et al. 2009; Tota-Maharaj \& Scholz 20Iо). As a filtering system, particulate-bound $\mathrm{P}$ within stormwater may be captured by the PP system; however, long-term observations are needed to determine if $\mathrm{P}$ is remobilized over time.

Design components within PP systems including geotextiles, phosphorus absorbing material or anaerobic zones may improve removal of nutrients and other contaminants but these techniques have not yet been thoroughly tested or studied. Tota-Maharaj \& Scholz (2010) performed laboratory simulations that demonstrated a geotextile can have significant effect on the removal of certain nutrients such as $\mathrm{NH}_{4}^{+}$and ortho-phosphate. Collins et al. (2010) observed that a concrete grid paver system, which included a sand layer, had lower $\mathrm{NO}_{2,3}-\mathrm{N}$ and $\mathrm{TN}$ concentrations than PPs without sand layers. Fach \& Geiger (2005) reported that crushed brick substrate as well as limestone gravel provided higher sorption of metals than crushed basalt.

Pollutants that are introduced into stormwater through the weathering of pavement and aggregates have yet to be thoroughly evaluated. Materials within a pavement structure are known to react chemically or dissolve overtime when exposed to stormwater, increasing the $\mathrm{pH}$, conductivity, alkalinity, hardness and concentration of total dissolved solids of exfiltrate (Sansalone \& Teng 2004). In particular, higher concentrations of calcium and magnesium have been observed in PP exfiltrate (Sansalone \& Teng 2004). Aggregate type undoubtedly has an effect on the water quality and chemistry of exfiltrated water but Fach \& Geiger's (2005) research is one of the few available examples where the influence of aggregate on water quality has been directly investigated. Over the course of a 3 year study, Fassman \& Blackbourn (2010b) observed that joint and bedding sand migrated into the drainage pipes. They concluded that the majority of all pollutants in water samples originated from sand material and not from inputs from the surface.

With the exception of salts, the potential for groundwater contamination as a result of infiltration through a PP system is low (Pitt et al. 1996). Salts, originating from road salting practices in cold climates, are generally poorly attenuated and migrate easily through the pavement and aggregate and, ultimately, to groundwater and surface water receiving systems. In underlying soils, cation replacement $\left(\mathrm{Na}^{+}\right.$for $\mathrm{Ca}^{2+}$ and $\left.\mathrm{Mg}^{2+}\right)$ can lead to the leaching or mobilization of several heavy metals and changes in physical soil structure (Marsalek 2003). Elevated levels of metals have been observed within exfiltrate in winter and the early spring months, but were attributed to increased loading rates at the PP surface (Boving et al. 2008; TRCA 2008). Since PP systems alter the timing, rate and volume of stormwater flows there may be opportunities to dilute seasonally high pollutant concentration but these processes have not been sufficiently assessed or critically evaluated.

A large body of research exists on the impacts of PPs on stormwater quality but conclusive performance statistics are limited. The quality of statistical analysis within the published literature remains variable and authors use a wide range of methods for interpreting results. Standardized reporting methods would be beneficial in making the water quality benefits of PPs more widely understood and accepted. The body of literature tends to emphasize percent removals rather than residual pollutant concentrations and there has been limited analysis of the variability of removal rates. There remain several research areas which require further investigation including: the source, fate and transportation of nutrients, the effect of material selection and drainage design on water quality, and the implications of stormwater infiltration on groundwater quality. PP research on water quality has been laboratory-based or at a site scale. The impact of catchment-scale installations of PPs and other LID practices on stormwater quality have not been investigated, in part due to the rarity of implementation at that scale.

\section{LONGEVITY AND FUNCTIONALITY}

The functional lifespan of a PP system is determined by the pavement's ability to meet hydrologic, water quality and other objectives. There are multiple mechanisms through which a PP system can potentially fail. First, if the pavement loses its permeability it will fail to meet necessary hydrologic and water quality objectives. Structural failures, such as excessive heaving, rutting, cracking and ravelling, can also prevent a pavement from meeting its functional objectives, including aesthetic and safety standards. Finally, as a pavement ages, dynamic pollutant removal mechanisms such 
as sorption, may ultimately be exhausted. If the capacity for pollutant removal is significantly diminished, a PP system may fail as a result of its inability to maintain the design stormwater quality objectives.

\section{Clogging and permeability losses}

PPs function as a passive filter and, as such, the filtration of particles and fines decreases the pavement's capability to infiltrate water over time. This process has been documented by numerous authors, but all stress that the effects of clogging on permeability should be reversible through the application of regular maintenance (Baladès et al. 1995; Colandini et al. 1995; Yong et al. 2008; Pezzaniti et al. 2009). The presence or impact of biofilms has not been addressed even though biofilm clogging could also reduce a PP system's permeability (Mothersill et al. 2000). Laboratory-based trials examining the clogging process of PPs and aggregates (Tan et al. 2003; Illgen et al. 2007; Brown et al. 2009; Pezzaniti et al. 2009; Haselbach 2010) have confirmed that with repeated exposure to fines, clogging occurs and surface infiltration rates decrease. These studies cannot provide realistic time estimates of the clogging process because laboratory simulations do not replicate the natural conditions as experienced by full-sized PP systems including the cycling of dry and wet conditions, biofilm growth, surface crusting, chemical (e.g. oil and chloride) inputs, vehicular loadings, variable rainfall, application of traction agents, and atmospheric deposition of sediments.

A reduction in surface permeability has a two-fold effect on the functionality of a PP system. If stormwater cannot infiltrate at a rate which exceeds precipitation rates, ponding and surface runoff will occur. Once a PP begins to behave as an impermeable surface the environmental benefits of the system, including reductions in peak flows and volumes and removal of stormwater pollutants, are lost. In order to prevent this outcome it is important to conduct surface maintenance and remove clogging material before the hydrologic and water quality functions of the system are significantly inhibited. Current knowledge does not allow for accurate prediction or modelling of surface clogging. Table 3 illustrates the mixed experiences from experimental and demonstration projects; in some cases PPs are shown to perform well even after multiple years of use, whereas in other cases permeability reductions are observed after only 1 or 2 years. In cold climates, pavements that are sanded as a result of winter maintenance have been observed to experience drastic permeability reductions, potentially over the course of a single winter (van Duin et al. 2008).

Observational studies have linked several conditions with rapid permeability reductions. Traffic loads are a major contributing factor in clogging and pavements subjected to higher traffic rates are more susceptible to permeability losses (Brattebo \& Booth 2003; James \& Gerrits 2003; Boving et al. 2008). In some instances, the use of geotextiles may inhibit infiltration. Noted in both field (Boving et al. 2008) and laboratory (Yong et al. 2008; Brown et al. 2009) studies, under certain conditions, geotextiles can act as a filter that results in accumulation of fine materials which form an impermeable barrier beneath the surface. There may also be conditions that help sustain permeability, such as plant growth and leaf litter (James \& Gerrits 2003).

Clogging of PPs will remain a serious and legitimate issue limiting the mainstream use of PPs as a LID technology, as long as the process is poorly understood and cannot be effectively predicted. Further investigation is needed to identify pavement designs which optimize pollutant retention and clogging resistance. Tools for designers such as models which can accurately predict gradual loss of permeability are needed. Some hydraulic modelling of PPs has been performed by Hohaia et al. (20II) and Schlüter \& Jefferies (2002) but these were short-term simulations and therefore did not incorporate long-term surface clogging processes. Tan et al. (2003) demonstrated that under laboratory conditions, where the gradation of the clogging material is known, empirical equations can be used to model permeability reductions of aggregate base layers. Analytical tools like these, used in combination with field observations, will assist engineers and managers in planning and timing maintenance and safeguarding pavement from failures due to clogging, while simultaneously eliminating the cost of unwarranted maintenance.

\section{Effects of frost}

PPs have repeatedly been shown to function in cold climates in North America and Europe (TRCA 2008; Roseen et al. 
Table 3 | Infiltration performance of aged PPS

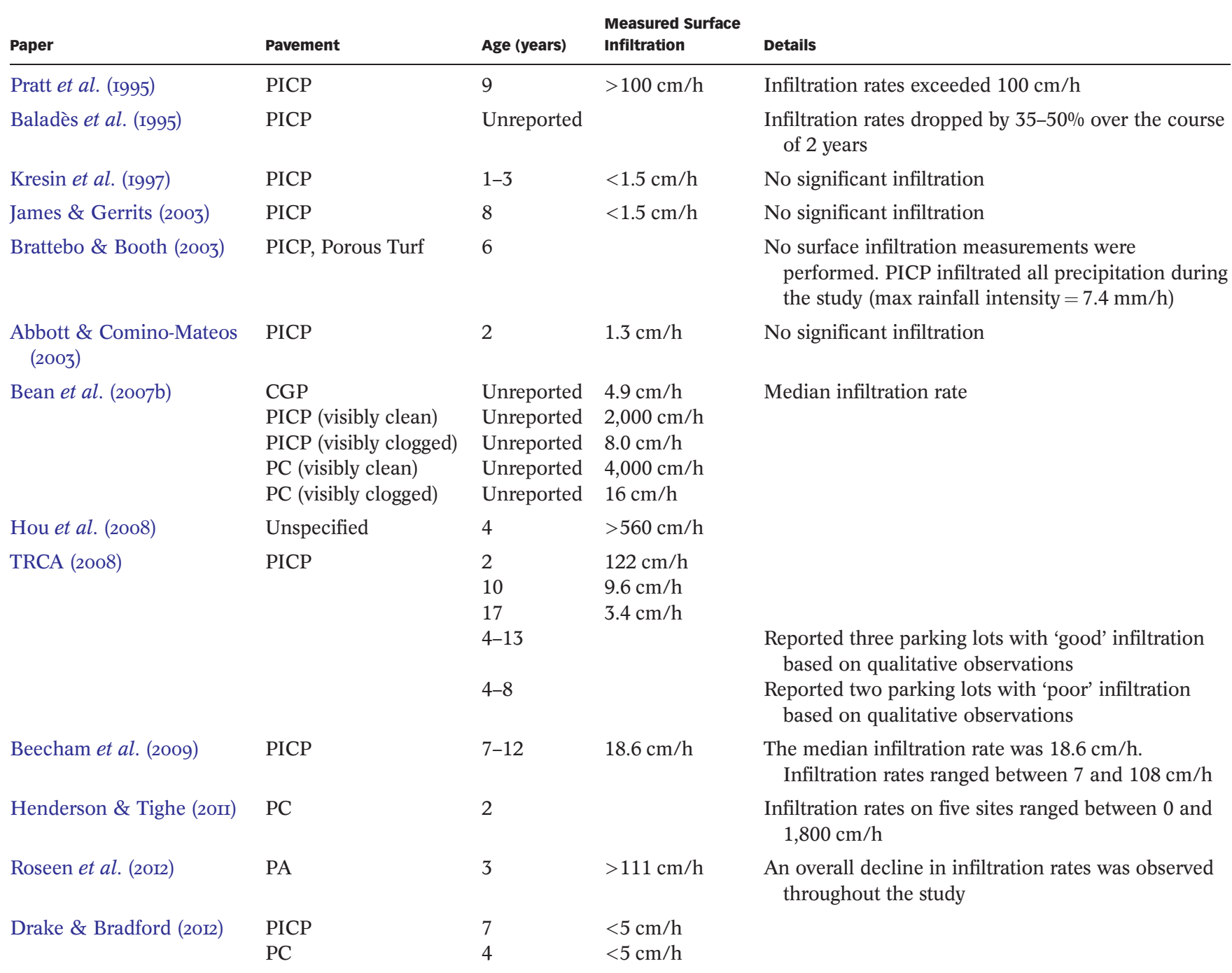

2009; Tyner et al. 2009; Gomez-Ullate et al. 20Io; Hou et al. 20Io). Roseen et al. (2009) observed only minimal changes in hydrologic performance between summer and winter seasons for a PA parking lot. Observations throughout a winter season by Tyner et al. (2009) noted that, even though air temperatures within sample plots of PC dropped below freezing on several occasions, water was not present within the storage volume when these temperatures occurred because the PP systems drain readily. It has been argued that PP systems are more resistant to freezing and, thus, are also more resistant to frost heave than impervious pavements (Bäckström 2000). Stormwater exfiltration causes higher moisture levels in underlying soils which increases the latent heat of the ground and postpones freezing within the pavement (Bäckström 2000; Kevern et al. 2009). Simultaneously, thawing processes are expedited by melt water infiltrating from the surface (Bäckström 2000; Kevern et al. 2009). In combination, these two processes lead to shorter periods of frost and shallow frost penetration reducing the overall risk of frost damage.

A 2 year study of a PA parking lot in Durham, NH (latitude of $43.11 \mathrm{~N}$ ) by Hou et al. (20IO) at the University of New Hampshire found that the PP performed extremely well in a northern climate. Neither the presence of frost 
nor freeze-thaw cycling affected the hydraulic integrity of the system. Many sections of pavement sustained surface infiltration measurements above $635 \mathrm{~cm} / \mathrm{h}$ through the winter and all permeability losses observed during the study were caused by mechanisms unassociated with frost, such as binder-drain down, over-compaction and the influx of clogging materials. In a laboratory study using PA specimens, Bäckström \& Bergström (2000) simulated the worstcase scenario of rapid freeze-thaw cycling occurring concurrently with precipitation. These simulations were designed to ensure that water froze within the PA instead of draining. Under this extreme scenario, the PA lost $90 \%$ of its original permeability but infiltration rates remained within $6-30 \mathrm{~cm} / \mathrm{h}$ which would be sufficient to infiltrate snowmelt delivered gradually to a PP system.

Freeze-thaw cycling is the principal cause of pavement breakdown in cold climates (Roseen et al. 2012). Poured PPs have experienced mixed success throughout cold climates. Many early PA and PC installations experienced degradation such as cracking, rutting and ravelling but as mix designs and construction practices improved poured PPs have become longer lasting (Roseen et al. 2012). Winter durability of PC has been tested and evaluated by several researchers (Cutler et al. 2010; Guthrie et al. 2010; Kevern et al. 2010). Specimen testing has shown that damage to PC as a result of freezethaw cycling occurs more rapidly when PC surfaces are clogged (Guthrie et al. 20I0). Exposure to deicers has been documented to cause scaling in PC. Cutler et al. (20I0) demonstrated that surface degradation is affected by deicer type (order of severity: $\mathrm{CaCl}_{2}>\mathrm{NaCl}>\mathrm{CMA}$ ) and mix design. Specimen testing performed by Kevern et al. (20I0) found that acceptable freeze-thaw performance can be achieved by using aggregates such as granite or highly durable river gravel in PC mixes.

\section{Long-term pollutant removal}

Very few studies have evaluated the potential for declining pollutant removal with time. Brattebo \& Booth (2003) noted both positive and negative changes in water quality after 6 years of use; concentrations of $\mathrm{Zn}$ in exfiltrated water increased while concentrations of $\mathrm{Cu}$ and $\mathrm{Pb}$ decreased. While $\mathrm{Zn}$ is more soluble than $\mathrm{Cu}$ or $\mathrm{Pb}$, to understand changes over time it is necessary to understand the speciation of the metals which are removed and the likelihood of remobilization (Murakami et al. 2008). In samples of road dust analysed by Murakami et al. (2008), $\mathrm{Cu}$ was in the form of organic complexes and carbonates whereas $\mathrm{Mn}, \mathrm{Zn}$ and $\mathrm{Cd}$ were likely to exist in the form of free ions. Laboratory simulations suggested that the free metal ions of $\mathrm{Mn}, \mathrm{Zn}$, and $\mathrm{Cd}$ were more likely to desorb from sediments (Murakami et al. 2008) supporting the findings of Brattebo \& Booth (2003). The relative mobility of $\mathrm{Cd}$ and $\mathrm{Zn}$ is given by their common presence in stormwater in the metal species which may be readily mobilized by changes in the ambient water chemistry (Marsalek et al. 2006). The capacity for pollutant removal over time and the possibility of remobilization has important implications for the potential contamination of groundwater systems.

Many researchers have noted that the majority of pollutants are captured near the pavement surface and within the first few centimetres of porous media (Barraud et al. 1999; Legret et al. 1999; James \& Gerrits 2003; Boving et al. 2008). Consequently, in terms of water quality objectives, PPs are far more likely to fail as a result of surface clogging than due to storage exhaustion. Pollutant concentrations in underlying soils measured by Legret \& Colandini (I999) noted no significant contamination below a PICP parking lot after 8 years of use. Soil samples collected, by removing pavers and aggregate materials, below seven parking lots by TRCA (2008), also displayed minimal contamination. Laboratory-based simulations have estimated that even after 50 years of stormwater infiltration the concentration of heavy metals in underlying soils will remain below regulation thresholds (Legret et al. 1999). This evidence suggests that infiltrated stormwater from PP systems is unlikely to significantly impact soil quality. The issues of chloride impacts on the mobility of chemicals stored in PP structures, or the effects of toxic spills, have not been fully addressed so far.

\section{MAINTENANCE NEEDS}

Maintenance is an essential practice for all infrastructure; it improves the day-to-day functionality of the system and, ultimately, extends the operational life of individual components. PPs operate as a dual system, providing 
pavement for transportation needs and drainage/infiltration, storage and treatment for stormwater management; consequently, maintenance practices must address both of these functional objectives. Sediment and debris buildup within a PP system are inescapable outcomes of urban runoff and thus operational activities such as monitoring, maintenance and rehabilitation are best management practices for $\mathrm{PP}$ systems.

In regions where PP systems are niche products, with limited use, it is still commonplace for property owners to operate the pavement solely as transportation infrastructure and to neglect the maintenance which sustains the hydraulic functionality of the pavement. Improper maintenance leads to a higher incidence of premature failure because clogging materials are not removed in a timely and regular manner and become embedded within the pavement. Loss of hydraulic functionality, induced by a lack of maintenance, propagates the perception that PP systems have a short effective life and do not provide reliable infiltration. Since operators are often unaware of the maintenance requirements of their PPs, performance failures, arising from excessive surface clogging, may be interpreted as inadequacies inherent to permeable product instead of associating the failure with improper care.
The studies which have attempted to test maintenance techniques and evaluate their effect on surface permeability (Baladès et al. I995; Kresin et al. I997; James \& Gerrits 2003; van Duin et al. 2008; Chopra et al. 20I0a, b; Henderson \& Tighe 20II) have mainly relied on hand-held equipment. Typically, these studies have reported results from tests from one or two parking lots and, therefore, results cannot be supported by statistical analysis or shown to be repeatable. Tables 4 and 5 summarize the key findings of the studies that have evaluated maintenance techniques. Many studies confirm that removing fines and sediments which collect on or near the surface of a PP provides partial or full restoration of surface infiltration rates (Kresin et al. r997; James \& Gerrits 2003). Nevertheless, there is insufficient knowledge with respect to the overall effectiveness of commercially practical removal techniques for various systems and conditions.

Baladès et al. (I995) were among the earliest researchers to test practical cleaning treatments on PICPs. They noted that as clogging becomes more pervasive, more intensive cleaning treatments are required and recommended suction for preventative maintenance and pressure washing for rehabilitative maintenance. Henderson \& Tighe (20II) tested surface treatments of multiple

Table 4 | Observed effects of cleaning practice

\begin{tabular}{|c|c|c|c|c|c|}
\hline Study & Pavement & $\begin{array}{l}\text { Age } \\
\text { (years) }\end{array}$ & Maintenance & $\begin{array}{l}\text { Post treatment } \\
\text { infiltration }(\mathrm{cm} / \mathrm{h})\end{array}$ & Level of rehabilitation \\
\hline $\begin{array}{l}\text { Kresin et al. } \\
\quad(\text { I997) }\end{array}$ & $\mathrm{PICP}$ & $1-3$ & $\begin{array}{l}\text { Manual removal of } \\
\text { material in top } 5 \mathrm{~mm}\end{array}$ & $\begin{array}{l}0.77(\text { Site } 1) \\
4.0(\text { Site } 2)\end{array}$ & $\begin{array}{l}\text { Negligible change } \\
\text { An increase of } 168 \%\end{array}$ \\
\hline $\begin{array}{l}\text { James \& Gerrits } \\
\quad(2003)\end{array}$ & PICP & 8 & $\begin{array}{l}\text { Manual removal of } \\
\text { material in top } \\
25 \mathrm{~mm}\end{array}$ & & $\begin{array}{l}\text { Post treatment infiltration rates for the } 1 \text { st plot (Eco- } \\
\text { Stone 3') only improved in areas of low traffic } \\
\text { Removal of material in top } 25 \mathrm{~mm} \text { provided partial } \\
\text { rehabilitation }\end{array}$ \\
\hline \multirow[t]{3}{*}{$\begin{array}{r}\text { Henderson \& } \\
\text { Tighe }(2 \mathrm{OII})\end{array}$} & \multirow[t]{3}{*}{$\mathrm{PC}$} & \multirow[t]{3}{*}{2} & Large hose & \multirow[t]{3}{*}{$70-1,300$} & $\begin{array}{l}\text { Over } 90 \% \text { of the treated area displayed improvement. } \\
\text { Significant results were observed }\end{array}$ \\
\hline & & & Hand held sweeping & & $\begin{array}{l}\text { Between } 20 \text { and } 80 \% \text { of the treated area displayed } \\
\text { improvement. Results were not significant }\end{array}$ \\
\hline & & & $\begin{array}{l}\text { Hand held sweeping } \\
\text { and power washing }\end{array}$ & & $\begin{array}{l}\text { Between } 50 \text { and } 90 \% \text { of the treated area displayed } \\
\text { improvement. Results were not significant }\end{array}$ \\
\hline \multirow[t]{3}{*}{$\begin{array}{l}\text { Chopra et al. } \\
\quad \text { (20IOa) }\end{array}$} & \multirow[t]{3}{*}{$\mathrm{PC}$} & $6-18$ & $\begin{array}{l}\text { Hand held vacuum } \\
\text { sweeping }\end{array}$ & 25.4 & \\
\hline & & $6-18$ & Pressure washing & 145 & \\
\hline & & $6-18$ & $\begin{array}{l}\text { Hand held vacuum } \\
\text { sweeping and } \\
\text { pressure washing }\end{array}$ & 170 & \\
\hline
\end{tabular}




\begin{tabular}{|c|c|c|c|c|}
\hline Study & Pavement & Age (years) & Maintenance & Level of rehabilitation \\
\hline \multirow{4}{*}{$\begin{array}{l}\text { Baladès et al. } \\
\quad \text { (I995) }\end{array}$} & PICP & 10 & Wetting and sweeping & Negative effect \\
\hline & & Unreported & Sweeping and vacuum sweeping & $\begin{array}{l}\text { Severely clogged surfaces showed no } \\
\text { improvement. Moderately clogged surfaces } \\
\text { were rehabilitated after two passes }\end{array}$ \\
\hline & & Unreported & Vacuum sweeping & $\begin{array}{l}\text { Partial or full rehabilitation was achieved after } \\
\text { two passes }\end{array}$ \\
\hline & & Unreported & Pressure washing & Partial or full rehabilitation was achieved \\
\hline \multirow[t]{4}{*}{$\begin{array}{l}\text { van Duin et al. } \\
\quad(2008)\end{array}$} & PA & $<1$ & $\begin{array}{l}\text { Schwarze A8000 Regenerative-air } \\
\text { truck (single dry pass) }\end{array}$ & $\begin{array}{l}\text { Maintenance decreased measured infiltration } \\
\text { rates }\end{array}$ \\
\hline & & & $\begin{array}{l}\text { Schwarze A8000 regenerative-air } \\
\text { truck (three wet passes) }\end{array}$ & Pavement appeared to be irreversibly clogged \\
\hline & PICP & $<1$ & $\begin{array}{l}\text { Schwarze A8000 Regenerative-air } \\
\text { truck (single dry pass) }\end{array}$ & $\begin{array}{l}\text { Measured infiltration rates improved in some } \\
\text { areas. Increases in infiltration related to depth } \\
\text { of joint material removed }\end{array}$ \\
\hline & & & $\begin{array}{l}\text { Schwarze A8000 regenerative-air } \\
\text { truck (three wet passes) }\end{array}$ & $\begin{array}{l}\text { Measured infiltration rates improved in some } \\
\text { areas. Increases in infiltration related to depth } \\
\text { of joint material removed }\end{array}$ \\
\hline \multirow[t]{8}{*}{$\begin{array}{l}\text { Chopra et al. } \\
\quad \text { (20Iob) }\end{array}$} & $\mathrm{PC}$ & $\begin{array}{l}\text { Specimen } \\
\text { simulations }\end{array}$ & $\begin{array}{l}\text { Loading of sand followed by Elgin } \\
\text { Whirlwind vacuum truck }\end{array}$ & Full rehabilitation was achieved after two passes \\
\hline & & & $\begin{array}{l}\text { Loading of limestone followed by } \\
\text { Elgin Whirlwind vacuum truck }\end{array}$ & Partial rehabilitation was achieved \\
\hline & Flexipave & $\begin{array}{l}\text { Specimen } \\
\text { simulations }\end{array}$ & $\begin{array}{l}\text { Loading of sand followed by Elgin } \\
\text { Whirlwind vacuum truck }\end{array}$ & No significant effect \\
\hline & & & $\begin{array}{l}\text { Loading of limestone followed by } \\
\text { Elgin Whirlwind vacuum truck }\end{array}$ & No significant effect \\
\hline & PICP & $\begin{array}{l}\text { Specimen } \\
\text { simulations }\end{array}$ & Loading of sand followed by vacuum & Full rehabilitation was achieved after two passes \\
\hline & & & $\begin{array}{l}\text { Loading of limestone followed by } \\
\text { vacuum truck }\end{array}$ & $\begin{array}{l}\text { Vacuum sweeping restored infiltration rates at } \\
\text { one location and failed at a second location }\end{array}$ \\
\hline & PA & $\begin{array}{l}\text { Specimen } \\
\text { simulations }\end{array}$ & $\begin{array}{l}\text { Loading of sand followed by vacuum } \\
\text { truck }\end{array}$ & $\begin{array}{l}\text { The first pass of the vacuum sweeper improved } \\
\text { infiltration rates but repeated passes decreased } \\
\text { infiltration }\end{array}$ \\
\hline & & & $\begin{array}{l}\text { Loading of limestone followed by } \\
\text { vacuum truck }\end{array}$ & No significant effect \\
\hline \multirow[t]{2}{*}{$\begin{array}{l}\text { Drake et al. } \\
\quad(\text { (2OI2) }\end{array}$} & PICP & 2 & Elgin Whirlwind vacuum truck & $\begin{array}{l}\text { Single pass of the vacuum sweeper partially } \\
\text { restored infiltration rates }\end{array}$ \\
\hline & $\mathrm{PC}$ & 2 & Elgin Whirlwind vacuum truck & No significant effect \\
\hline
\end{tabular}

permeability. Similarly, Chopra et al. (2010a) found pressure washing to better rejuvenate PC cores than vacuum sweeping in laboratory experiments. Chopra et al. (20Iob) also conducted field tests with an Elgin Whirlwind MV truck on five types of PP (FlexiPave, PC, PA, and two types of PICPs) which had been artificially clogged.
PC parking lots in 2009 and recommended the practice of washing surfaces with a large diameter hose to renew permeability. Henderson \& Tighe (20II) also observed that other surface treatments, such as sweeping with a push broom, vacuum sweeping with a shop-vac and power washing, did not provide significant improvements to pavement 
High groundwater levels complicated the study and influenced results but observations still showed that vacuum sweeping could restore some permeability. The research highlighted that clogging processes and the effectiveness of subsequent rejuvenation practices is affected by the type of PP (Chopra et al. 20Iob).

Understanding and evaluating the effects of maintenance remains one of the most important and pressing topics for PP research. Current work assessing maintenance tends to overemphasize the overall effectiveness of specific maintenance practices and underemphasize uncertainties created by localized conditions during data collection and experimental procedures. None of the published studies provide any estimates of the overall effective-life of the studied PP systems, most likely because the reported results are inconclusive. Based on review of the available literature, several trends have been identified:

- The effectiveness of cleaning treatments decreases with repeated exposure to clogging materials.

- Clogging causes irreversible decreases in permeability. Based on existing publications, cleaning practices are likely to provide partial restoration, but not full restoration of surface infiltration rates.

- Within an individual PP system the effectiveness of maintenance is highly variable and inconsistent.

- Large-scale effective maintenance practices have been successfully demonstrated under limited circumstances.

- The effectiveness of cleaning practices on surface permeability is dependent on PP type.

It is the authors' conclusion that the current research does not provide sufficient evidence to conclude that maintenance, as executed in the published studies, will provide a significant and lasting level of restoration. Published works have almost exclusively reported results from isolated experiments and long-term investigations are needed to help clarify the effects of regularly organized maintenance on the overall effective-life of a PP system. Without reliable and repeatable evidence of the effects that maintenance has on long-term functionality, comparisons to conventional pavements regarding operational costs and effective lifespans remain highly questionable.

\section{EMERGING RESEARCH AND RESEARCH NEEDS}

\section{Costing and performance studies beyond site-scale}

Life-cycle analyses and costing information is required to foster acceptance of PP systems as viable mainstream alternatives to traditional impervious pavements and traditional drainage systems. As a dual system, providing infrastructure for transportation and stormwater management, cost comparisons must account for the drainage infrastructure that is replaced or reduced as a result of the infiltration and storage provided by a PP system. Implementation of PP, along with other LID technologies, is impeded by a lack of reliable and accurate cost data (Roy et al. 2008). Additionally, without verifiable effective-life estimates and proven maintenance practices, the operational costs and true life-cycle cost of this technology remain unclear. The cost-effectiveness of PPs and LID practices, as a whole, are scale-dependent with the largest potential benefits resulting from distributed implementation of a combination of LIDs and, thus, costing and life-cycle analysis is needed at both the lot-level and the community-level.

Decentralizing stormwater management through the application of PP systems, as well as other LIDs, will only produce desired environmental outcomes if oversight and watershed-scale management exist. Studies are needed at this large scale to demonstrate the capacity of PP systems to achieve and sustain environmental benefits within the context of large urban catchments. PP systems installed in a piecemeal fashion without due consideration of the implications to the larger watershed are unlikely to maximize overall net environmental benefits (Roy et al. 2008). Note that an analogous argument can be made about LID; so far, LID benefits have not been demonstrated in the receiving waters at the catchment level (Roy et al. 2008). Assessment tools are needed to provide decision support for developers and policy makers. There are only a few publications which demonstrate costing and decision-making tools for LIDs (Montalto et al. 2007; Stovin \& Swan 2007). The authors of this review are not aware of any life-cycle, cost assessments or selection tools which offer comparisons between alternative PP products. Montalto et al. (2007) developed an assessment tool to evaluate the cost-effectiveness of various 
LID systems, including PPs, as a means of reducing combined-sewer overflows using hydrological and cost accounting methods. Although the Montalto et al. (2007) example applies only to combined sewer systems, tools like this allow different design and management scenarios to be evaluated quickly ensuring that environmental benefits are maximized and costs are minimized.

\section{Effects on Urban Heat Island}

Urban centres often experience warmer conditions than their rural surrounding as a result of human activities; this phenomenon is known as an Urban Heat Island. Studies monitoring pavement temperatures have observed minor to moderate differences between permeable and impermeable pavements, offering evidence that PP systems may mitigate heat island effects. Asaeda \& Ca (2000) studied the surface and internal temperatures of several pavement materials during summer conditions and demonstrated that a PICP, which has a higher reflectivity than asphalt, can still have very similar diurnal temperatures if the pavers have high thermal conductivity. In Asaeda and Ca's study, a pervious ceramic pavement produced cooler conditions than PICPs or asphalt. It was proposed that the smaller pore size of the ceramic pavement retained more water near the surface increasing evaporation rates during the day and keeping the pavement cool (Asaeda \& Ca 2000).

It is widely assumed that PP systems provide improved growing conditions for urban trees, compared to impervious pavement, by supplying air and moisture to the root system. However, there is limited evidence which has documented measureable increases in tree growth, health or longevity. Volder et al. (2009) monitored growth rates of mature trees surrounded by asphalt, concrete and PC but did not observe any significant differences in growth. Research results have not observed significant differences in soil moisture underlying permeable or impermeable pavements (Morgenroth \& Buchan 2009; Volder et al. 2009). Research has shown that plant growth is more affected by pavement design than pavement type. Tree specimens monitored by Morgenroth (20II) had increased root growth beneath PP systems designed with an uncompacted subbase and a gravel base, whereas PP systems without these design features had growth rates that were comparable to impervious pavements. In a separate study of seedling growth parameters, Morgenroth \& Visser (20II) also concluded that PPs improve tree growth only when the pavement design includes an uncompacted aggregate base.

\section{CONCLUSIONS}

Even though the study of PPs, as LID system components and infiltration practices, has been ongoing since the 1980s, PP products have not received widespread use throughout many parts of Canada and the USA. Their lack of mainstream use throughout Canada and the USA reveals that developers, designers, engineers and planners have not been given sufficient tools and knowledge to foster acceptance of this technology. Stormwater engineering designs need to cope with uncertain risks and thus long-term PP performance data should generate confidence that these systems can provide the same degree of safety and reliability as traditional end-of-pipe stormwater management measures. Comprehensive summaries, like this review, which outline the current state of knowledge are one instrument for promoting understanding and acceptance of PPs. Industry can better communicate realistic product cost comparisons, effectivelife information and maintenance costs. Government agencies can develop incentive programmes to ensure that costs and benefits are fairly distributed between developers and residents. And, lastly, design tools, long-term performance modelling and decision-making tools will support designers and planners considering the use of PPs.

As public interest in PP systems grows there is an increased need to critically evaluate the performance, practicality and, in some instances, the limitations of this technology. Throughout this review gaps in the current research as well as future research needs have been identified and can be summarized as follows.

1. Further performance demonstration with partial-infiltration to low permeability soils is needed. The impact of boundary conditions on infiltration and water quality has not been thoroughly investigated and is a critical component in maximizing environmental benefits.

2. Analyses of impacts on water quality must become more sophisticated and extend beyond EMCs to include total 
load reduction, censored data (i.e. concentrations below detection levels) and frequency analysis.

3. The processes connected with permeability reductions remain poorly understood and prohibit the development of accurate effective-life estimates. The effects of vegetation on PP functionality and performance, and control of weeds invading PP, also require further study.

4. More critical assessments and testing of maintenance practices are required. Commercially-available equipment needs to be rigorously tested and repeatable results should be demonstrated. Different PP types will likely require different maintenance practices and this has yet to be thoroughly examined.

5. Catchment and watershed-scale studies are needed to quantify the cumulative effects of multiple installations on urban hydrology and water quality. Cost-analysis for the small and large-scale adoption of PP systems is needed.

6. There is a continuing need for long-term studies to determine the performance and functionality of PPs over time.

PPs have been successfully implemented in cold climates and areas with low permeability soils. The PP systems discussed in this review have been shown to significantly mitigate many of the negative effects of urban development. PPs alleviate stresses on receiving surface water by substantially reducing runoff volumes, delaying flows and limiting peak flow rates. And, for small hydrologic events, PPs effectively capture and infiltrate all precipitation, substantially limiting the overall frequency of urban runoff flows. PP systems have proven to improve urban water quality by capturing suspended sediments and heavy metals, and reducing waste heat input into receiving waters. PPs capture and treat hydrocarbons and under certain conditions promote favourable nutrient transformations. So far, large potential benefits to surface water quality have been shown while, with the exception of chlorides in cold climates, risks to receiving groundwater systems and soils appear to be limited.

\section{REFERENCES}

Abbott, C. \& Comino-Mateos, L. 2003 In-situ hydraulic performance of a permeable pavement sustainable urban drainage system. J. Chart. Inst. Water Eng. 17 (3), 187-190.
Asaeda, T. \& Ca, V. 2000 Characteristics of permeable pavement during hot summer weather and impact on the thermal environment. Build. Environ. 35 (4), 363-375.

Bäckström, M. 2000 Ground temperature in porous pavement during freezing and thawing. J. Transp. Eng. 126 (5), 375-381.

Bäckström, M. \& Berström, A. 2000 Draining function of porous asphalt during snowmelt and temporary freezing. Can. J. Civ. Eng. 27 (3), 594-598.

Baladès, J.-D., Legret, M. \& Madiec, H. 1995 Permeable pavements: pollution management tools. Water Sci. Technol. 32 (1), 49-56.

Barraud, S., Gautier, A., Bardin, J. \& Riou, V. 1999 The impact of intentional stormwater infiltration on soil and groundwater. Water Sci. Technol. 39 (2), 185-192.

Barrett, M. 2008 Effects of a permeable friction course on highway runoff. J. Irrig. Drain. Eng. 134 (5), 646-651.

Barrett, M., Kearfott, P. \& Malina, J. 2006 Stormwater quality benefits of a porous friction course and its effect on pollutant removal by roadside shoulders. Water Environ. Res. 78 (11), 2177-2185.

Bean, E., Hunt, W. \& Bidelspach, D. 2007a Evaluation of four permeable pavement sites in eastern north Carolina for runoff reduction and water quality impacts. J. Irrig. Drain. Eng. 133 (6), 583-592.

Bean, E., Hunt, W. \& Bidelspach, D. 2007b Field survey of permeable pavement surface infiltration rates. J. Irrig. Drain. Eng. 133 (3), 249-255.

Beecham, S. \& Myers, B. 2007 Structural and design aspects of porous and permeable block pavement. J. Aust. Ceram. Soc. 43 (1), 74-81.

Beecham, S., Pezzaniti, D., Myers, B., Shackel, B. \& Pearson, A. 2009 Experience in the application of permeable interlocking concrete paving in Australia. 9th International Conference on Concrete Block Paving. Small Element Paving Technologies, Buenos Aires, pp. 18-21.

Booth, D. \& Leavitt, J. I999 Field evaluation of permeable pavement systems for improved stormwater management. J. Am. Plann. Assoc. 65 (3), 314-325.

Boving, T., Stolt, M., Augenstern, J. \& Brosnan, B. 2008 Potential for localized groundwater contamination in a porous pavement parking lot setting in Rhode Island. Environ. Geol. 55 (3), 571-582.

Brattebo, B. \& Booth, D. 2003 Long-term stormwater quantity and quality performance of permeable pavement systems. Water Res. 37 (18), 4369-4376.

Brown, C., Chu, A., van Duin, B. \& Valeo, C. 2009 Characteristics of sediment removal in two types of permeable pavement. Water Qual. Res. J. Can. 44 (1), 59-70.

Chopra, M., Kakuturu, S., Ballock, C., Spence, J. \& Wanielista, M. 20Ioa Effect of rejuvenation methods on the infiltration rates of pervious concrete pavements. J. Hydrol. Eng. 15 (6), 426-433.

Chopra, M., Stuart, E. \& Wanielista, M. 2orob Pervious Pavement Systems in Florida - Research Results. Low Impact Development 2010: Redefining Water in the City. ASCE, San Francisco, pp. 193-206. 
Coffman, L. 2000 Low-impact Development Design Strategies, an Integrated Design Approach. Program and Planning Division, Department of Environmental Resources. Price George's County, Maryland.

Colandini, V., Legret, M., Brosseaud, Y. \& Baladès, J.-D. 1995 Metallic pollution in clogging materials of urban porous pavements. Water Sci. Technol. 32 (1), 57-62.

Collins, K., Hunt, W. \& Hathaway, J. 2008 Hydrologic comparison of four types of permeable pavement and standard asphalt in easter North Carolina. J. Hydrol. Eng. 13 (12), 1146-1157.

Collins, K., Hunt, W. \& Hathaway, J. 2oro Side-by-side comparison of nitrogen species removal for four types of permeable pavement and standard asphalt in eastern North Carolina. J. Hydrol. Eng. 15 (6), 512-521.

Cutler, H., Wang, K., Schaefer, V. \& Kevern, J. 2010 Resistance of Portland cement pervious concrete to deicing chemicals. Transp. Res. Rec. 2164, 98-104.

CVC \& TRCA 2010 Low Impact Development Stormwater Management Manual. Credit Valley Conservation and Toronto and Region Conservation, Toronto.

Dietz, M. 2007 Low impact development practices: a review of current research and recommendations for future directions. Water Air Soil Pollut. 186 (1-4), 351-363.

Drake, J. \& Bradford, A. 2012 Assessing the Potential for Rehabilitation of Surface Permeability using Regenerative Air and Vacuum-Sweeping Trucks. 2012 CHI Monograph. Computational Hydraulics Int., Guelph.

Drake, J., Bradford, A. \& Van Seters, T. 2012 Evaluation of Permeable Pavements in Cold Climates - Kortright Centre. Toronto and Region Conservation Authority, Vaughan.

Dreelin, E., Fowler, L. \& Carroll, R. 2006 A test of porous pavement effectiveness on clay soils during natural storm events. Water Res. 40 (4), 799-805.

Fach, S. \& Geiger, W. 2005 Effective pollutant retention capacity of permeable pavements for infiltrated road runoffs determined by laboratory tests. Water Sci. Technol. 51 (2), 37-45.

Fassman, E. \& Blackbourn, S. 2oroa Urban runoff mitigation by a permeable pavement system over impermeable soils. J. Hydrol. Eng. 15 (6), 475-485.

Fassman, E. \& Blackbourn, S. 2orob Permeable Pavement Preformance over 3 Years of Monitoring. Low Impact Development 2010: Redefining Water in the City. ASCE, San Francisco, pp. 152-165.

Ferguson, B. 2005 Porous Pavements. CRC Press, Boca Raton.

Field, R., Masters, H. \& Singer, M. I982a Porous pavement: research; development; and demonstration. Transp. Eng. J. ASCE 108, 244.

Field, R., Masters, H. \& Singer, M. I982b Status of porous pavement research. Water Res. 16 (6), 849-857.

Fujita, S. 1997 Measures to promote stormwater infiltration. Water Sci. Technol. 36 (8-9), 289-293.

Gomez-Ullate, E., Bayon, J., Coupe, S. \& Castro-Fresno, D. 2010 Perfomance of pervious pavement parking bays storing rainwater in the north of Spain. Water Sci. Technol. 62 (3), 615-621.

Guthrie, W., DeMille, C. \& Eggett, D. 2010 Effects of soil clogging and water saturation on freeze-thaw durability of pervious concrete. Transp. Res. Rec. 2164, 89-97.

Haselbach, L. 20Io Potential for clay clogging of pervious concrete under extreme conditions. J. Hydrol. Eng. 15 (1), 67-69.

Henderson, V. \& Tighe, S. 2oII Evaluation of pervious concrete pavement permeability renewal maintenance methods at field sites in Canada. Can. J. Civ. Eng. 38 (12), 1404-1413.

Hohaia, N., Fassman, E., Hunt, W., Kelly, P. \& Collins, K. 20 II Hydraulic and hydrologic modelling of permeable pavement. World Environmental and Water Resources Congress. ASCE, San Francisco, pp. 587-597.

Hou, L., Feng, S., Ding, Y., Zhang, S. \& Huo, Z. 2008 Experimental study on rainfall-runoff relation for porous pavements. Hydrol. Res. 39 (3), 181-190.

Hou, K., Roseen, R., Ballestero, T., Briggs, J. \& Houle, J. 2010 Examination of pervious concrete and porous asphalt pavements performance for stormwater management in northern climates. Low Impact Development 2010: Redefining Water in the City. ASCE, San Francisco, pp. 1281-1298.

Illgen, M., Harting, K., Schmitt, T. \& Welker, A. 2007 Runoff and infiltration characteristics of pavement structures-review of an extensive monitoring program. Water Sci. Technol. 55 (10), 133-140.

James, W. \& Gerrits, C. 2003 Maintenance of infiltration in modular interlocking concrete pavers with external drainage cells. In: Practical Modeling of Urban Stormwater Systems, Vol. 11 (W. James, ed.). Computational Hydraulics International, Guelph, pp. 417-435.

James, W. \& Shahin, R. 1998 A laboratory examination of pollutants leached from four different pavements by acid rain. In: Advances in Modeling the Management of Stormwater Impacts, Vol. 6 (W. James, ed.). Computational Hydraulics International, Guelph, pp. 417-435.

James, W. \& Thompson, M. 1997 Contaminants from four new pervious and impervious pavements in a parking-lot. In: Advancements in Modeling the Management of Stormwater Impacts, Vol. 5 (W. James, ed.). Computational Hydraulics International, Guelph, pp. 207-222.

James, W. \& Verspagen, B. 1997 Thermal enrichment of stormwater by urban pavement. In: Advances in Modeling the Management of Stormwater Impacts, Vol. 5 (W. James, ed.). Computational Hydraulics International, Guelph, pp. 155-177.

Kevern, J., Schaefer, V. \& Wang, K. 2009 Temperature behavior of pervious concrete systems. Transp. Res. Rec. 2098, 94-101.

Kevern, J., Wang, K. \& Schaefer, V. 2oIo Effect of coarse aggregate on the freeze-thaw durability of pervious concrete. J. Mater. Civ. Eng. 22 (5), 469-475.

Knapton, J. \& Cook, I. 2000 Permeable paving for a new contaner handling area at Santos container ports, JIPEA World Congress. Tokyo: International Conference for Concrete Block Pavers, Brazil, pp. 398-406. 
Knapton, J. \& Cook, I. 2003 The use of permeable pavers in the reconstruction of the fire training ground at Jersey airport. Pave Africa: the 7th International Conference on Concrete Block Paving. Sun City: International Conference on Concrete Block Pavers. Available from: http://www.icpi.org/node/2668 (accessed 11 April 2013).

Kresin, C., James, W. \& Elrick, D. 1997 Observations of infiltration through clogged porous concrete block pavers. In: Advances in Modeling the Management of Stormwater Impacts, Vol. 5 (W. James, ed.). Computation Hydraulics International, Guelph, pp. 191-205.

Kwiatkowski, M., Welker, A., Traver, R., Vanacore, M. \& Ladd, T. 2007 Evaluation of an infiltration best management practice utilizing pervious concrete. J. Am. Water Resour. Assoc. 43 (5), 1208-1222.

Legret, M. \& Colandini, V. Ig99 Effects of a porous pavement with reservoir structure on runoff water: water quality and fate of heavy metals. Water Sci. Technol. 39 (2), 111-117.

Legret, M., Colandini, V. \& Le Marc, C. 1996 Effects of a porous pavement with reservoir structure on the quality of runoff water and soil. Sci. Total Environ. 189/190, 335-340.

Legret, M., Nicollet, M., Miloda, P., Colandini, V. \& Raimbault, G. I999 Simulation of heavy metal pollution from stormwater infiltration through a porous pavement with reservoir structure. Water Sci. Technol. 39 (2), 119-125.

Marsalek, J. 2003 Road salts in urban stormwater: an emerging issue in stormwater management in cold climates. Water Sci. Technol. 48 (9), 61-70.

Marsalek, J. \& Chocat, B. 2002 International report: stormwater management. Water Sci. Technol. 46 (6), 1-17.

Marsalek, J., Watt, E. W. \& Anderson, B. C. 2006 Trace metal levels in sediments deposited in urban stormwater management facilities. Water Sci. Technol. 53 (2), 175-183.

Ministry of Environment and Energy (MOE) I994 Water Management Policies Guidelines Provincial Water Quality Objectives. Queen's Printer for Ontario, Toronto.

Montalto, F., Behr, C., Alfredo, K., Wolf, M., Arye, M. \& Walsh, M. 2007 Rapid assessment of the cost-effectiveness of low impact development for CSO control. Landscape Urban Plan. 82 (3), 117-131.

Morgenroth, J. 20II Root growth response of Platanus orientalis to porous pavements. Arboric. Urban For. 37 (2), 45-50.

Morgenroth, J. \& Buchan, G. 2009 Soil moisture and aeration beneath pervious and impervious pavements. Arboric. Urban For. 35 (3), 135-141.

Morgenroth, J. \& Visser, R. 20II Above ground growth response of Platanus orientalis to porous pavements. Arboric. Urban For. 37 (1), 1-5.

Mothersill, C., Anderson, B., Watt, W. \& Marsalek, J. 2000 Biological filtration of stormwater: field operations and maintenance experiences. Water Qual. Res. J. Canada 35 (3), 541-562.

Murakami, M., Nakajima, F. \& Furumai, H. 2008 The sorption of heavy metal species by sediments in soakaways receiving urban road runoff. Chemosphere 70 (10-11), 2099-2109.
Newman, A., Pratt, C., Coupe, S. \& Cresswell, N. 2002 Oil biodegradation in permeable pavements by microbial communities. Water Sci. Technol. 45 (7), 51-56.

Pagotto, C., Legret, M. \& Le Cloirec, P. 2000 Comparison of the hydraulic behaviour and the quality of highway runoff water according to the type of pavement. Water Res. 34 (18), 4446-4454.

Pezzaniti, D., Beecham, S. \& Kandasamy, J. 2009 Influence of clogging on the effective life of permeable pavements. Water Manage. 62 (WM3), 211-220.

Pitt, R., Clark, S., Parmer, K. \& Field, R. 1996 Groundwater Contamination from Stormwater Infiltration. Ann Arbor Press, Inc., Chelsea.

Pratt, C., Mantle, J. \& Schofield, P. I989 Urban stormwater reduction and quality improvement through the use of permeable pavements. Water Sci. Technol. 21 (8), 769-778.

Pratt, C., Mantle, J. \& Schofield, P. 1995 UK research into the performance of permeable pavement, resevoir structures in controlling stormwater discharge quantity and quality. Water Sci. Technol. 32 (1), 63-69.

Pratt, C., Newman, A. \& Bond, P. 1999 Mineral oil bio-degradation within a permeable pavement: long term observations. Water Sci. Technol. 39 (2), 103-109.

Roseen, R., Ballestero, T., Houle, J., Avellaneda, P., Briggs, J. \& Wildey, R. 2009 Seasonal performance variations for stormwater management systems in cold climate conditions. J. Environ. Eng. 135 (3), 128-137.

Roseen, R., Ballestero, T., Houle, J., Briggs, J. \& Houle, K. 2012 Water quality and hydrologic perfomance of a porous asphalt pavement as a storm-water treatment strategy in a cold climate. J. Environ. Eng. 138 (1), 81-89.

Roy, A., Wenger, S., Fletcher, T., Walsh, C., Ladson, A., Shuster, W., Thurston, H. \& Brown, R. 2008 Impediments and solutions to sustainable, watershed-scale urban stormwater management: lessons from Australia and the United States. Environ. Manage. 42 (2), 344-359.

Rushton, B. 200I Low-impact parking lot design reduces runoff and pollutant loads. J. Water Resour. Plann. Manage. 172 (3), 172-179.

Sansalone, J., Kuang, X. \& Ranieri, V. 2008 Permeable pavement as a hydraulic and filtration interface for urban drainage. J. Irrig. Drain. Eng. 134 (5), 666-674.

Sansalone, J. \& Teng, Z. 2004 In situ partial exfiltration of rainfall runoff. I: Quality and quantity attenuation. J. Environ. Eng. 130 (9), 990-1007.

Schaefer, V., Kevern, J., Izevbekhai, B., Wang, K., Cutler, H. \& Wiegand, P. 20Io Construction and performance of pervious concrete overlay at Minnesota Road research project. Transp. Res. Rec. 2164, 82-88.

Schlüter, W. \& Jefferies, C. 2002 Modelling the outflow from a porous pavements. Urban Water 4 (3), 245-253.

Starke, P., Göbel, P. \& Coldewey, W. 2ого Urban evaporation rates for water-permeable pavements. Water Sci. Technol. 62 (5), 1161-1169. 
Starke, P., Göbel, P. \& Coldewey, W. 2orn Effects on evaporation rates from different water-permeable pavement designs. Water Sci. Technol. 63 (11), 2619-2627.

Stovin, V. \& Swan, A. 2007 Retrofit SuDS - cost estimates and decision-support tools. Proc. Inst. Civ. Eng. Water Manage. 160 (WM4), 207-214.

Tan, S., Fwa, T. \& Han, C. 2003 Clogging evaluation of permeable bases. J. Transp. Eng. 129 (3), 309-315.

Thelen, E., Grover, W., Hoiberg, A. \& Haigh, T. 1972 Investigation of Porous Pavements for Urban Runoff Control. US Environmental Protection Agency, Office of Research and Monitoring, Philadelphia.

Tota-Maharaj, K. \& Scholz, M. 2oIo Efficiency of permeable pavement systems for the removal of urban runoff pollutants under varying environmental conditions. Environ. Prog. Sust. Energy 29 (3), 358-369.

TRCA 2008 Performance Evaluation of Permeable Pavement and a Bioretention Swale. Toronto and Region Conservation, Sustainable Technologies Evaluation Program, Toronto.

Tyner, J., Wright, W. \& Dobbs, P. 2009 Increasing exfiltration from pervious concrete and temperature monitoring. J. Environ. Manage. 90 (8), 2535-2541.
US EPA I986 Quality Criteria for Water. Office of Water Regulations and Standards, Washington, DC. EPA/440/5-86-001.

van Duin, B., Brown, C., Chu, A., Marsalek, J. \& Valeo, C. 2008 Characterization of long-term solids removal and clogging processes in two types of permeable pavement under cold climate conditions. 11th International Conference on Urban Drainage. Edinburgh, pp. 1-10.

Volder, A., Watson, T. \& Viswanathan, B. 2009 Potential use of pervious concrete for maintaining exisiting mature trees during and after urban development. Urban Forest. Urban Green. 8 (4), 249-256.

Walsh, C., Fletcher, T. \& Ladson, A. 2005 Stream restoration in urban catchments through redesign stormwater systems: looking to the catchment to save the stream. J. N. Am. Benthol. Soc. 21 (3), 690-705.

Watanabe, S. 1995 Study on storm water control by permeable pavement and infiltration pipes. Water Sci. Technol. 32 (1), 25-32.

Yong, C., Deletic, A., Fletcher, T. \& Grace, M. 2008 The clogging behaviour and tretment efficiency of a range of porous pavements. 11th International Conference on Urban Drainage. Edinburgh, pp. 1-10.

First received 1 November 2012; accepted in revised form 19 February 2013 